\title{
Hematoma após Anestesia Peridural: Tratamento Conservador. Relato de Caso*
}

\author{
Hematoma after Epidural Anesthesia: Conservative Treatment. \\ Case Report
}

\author{
Edno Magalhães, TSA ${ }^{1}$, Cátia Sousa Govêia, TSA², Luís Cláudio de Araújo Ladeira, TSA², Laura Elisa Sócio de Queiroz ${ }^{3}$
}

\section{RESUMO}

Magalhães E, Govêia CS, Ladeira LCA, Queiroz LES - Hematoma após Anestesia Peridural: Tratamento Conservador. Relato de Caso.

JUSTIFICATIVA E OBJETIVOS: O hematoma associado à compressão espinhal após anestesia peridural é uma complicação neurológica grave, apesar da pequena incidência relatada (1:150.000). É um episódio agudo, e o tratamento tradicionalmente aplicado é a descompressão cirúrgica de urgência. Mais recentemente, em casos específicos, o tratamento com corticosteróide tem sido aplicado como alternativa, com boa recuperação neurológica. $O$ objetivo deste relato foi expor um caso de hematoma peridural com tratamento conservador e recuperação neurológica completa.

RELATO DO CASO: Paciente do sexo feminino, 34 anos, estado físico ASA I, sem qualquer histórico de coagulopatia ou terapia anticoagulante, submetida à anestesia peridural com punção única, em $L_{2}-L_{3}$, para tratamento cirúrgico de varizes nos membros inferiores. Oito horas após a anestesia regional, ela ainda apresentava bloqueio motor completo (escala de Bromage), redução das sensibilidades térmica e dolorosa abaixo do nível $L_{3}$, hiperalgesia na região plantar esquerda, preservação dos reflexos tendinosos e ausência de dor lombar. A tomografia computadorizada revelou hematoma peridural em $L_{2}$ com compressão do saco dural. Dez horas após a punção peridural não havia progressão dos sinais e sintomas neurológicos. Optou-se, então, pelo tratamento com metilprednisolona em infusão venosa contínua $\left(5,3 \mathrm{mg} \cdot \mathrm{kg}^{-1}\right.$ na primeira hora e 1,4 mg. $\mathrm{kg}^{-1} \cdot \mathrm{h}^{-1}$ nas 23 horas subseqüentes). Oito horas após o início do tratamento, a paciente recuperou as sensibilidades térmica e dolorosa, e houve regressão total do bloqueio motor. $\mathrm{Na} 12^{a}$ hora, deambulava e referia dor na ferida operatória. O hematoma peridural não foi visualizado em nova tomografia computadorizada na $14^{a}$ hora após o início do tratamento. A paciente recebeu alta hospitalar 86 horas depois do início do tratamento conservador, sem comprometimento neurológico. Uma tomografia computadorizada de controle, após sete meses, mostrou o canal vertebral completamente normal.

${ }^{*}$ Recebido do (Received from) Hospital Universitário de Brasília - Universidade de Brasília (UnB), Brasília, DF

1. Professor Adjunto da Área de Clínica Cirúrgica da FM-UnB; Responsável pelo CET do Centro de Anestesiologia da UnB

2. Médico Assistente da Clínica de Anestesiologia do HU de Brasília (UnB); Co-Responsável pelo CET do Centro de Anestesiologia da UnB

3. Médica Assistente do Hospital Regional de Sobradinho

Apresentado (Submitted) em 24 de abril de 2006

Aceito (Accepted) para publicação em 27 de novembro de 2006

Endereço para correspondência (Correspondence to):

Dr. Edno Magalhães

SQS 113, Bloco C/406

70736-030 Brasília, DF

E-mail: ednomag@gmail.com

() Sociedade Brasileira de Anestesiologia, 2007
CONCLUSÕES: A eficiência da abordagem conservadora mostrou-se uma alternativa importante à intervenção cirúrgica em casos específicos. A avaliação da progressão ou a estabilização do comprometimento neurológico, sobretudo após a oitava hora após a punção peridural, é essencial para a escolha do tratamento.

Unitermos: COMPLICAÇÕES: compressão de medula espinhal, hematoma peridural; TÉCNICAS ANESTÉSICAS, Regional: peridural.

\section{SUMMARY}

Magalhães E, Govêia CS, Ladeira LCA, Queiroz LES - Hematoma after Epidural Anesthesia: Conservative Treatment. Case Report.

BACKGROUND AND OBJECTIVES: Hematoma associated with spinal compression after epidural anesthesia is a severe neurological complication, despite the reduced incidence reported $(1: 150,000)$. It is an acute episode and the traditional treatment includes urgent surgical decompression. More recently, treatment with corticosteroids has been used as an alternative, in specific cases, with good neurological resolution. The objective of this report was to present the case of an epidural hematoma treated conservatively with complete neurological recovery.

CASE REPORT: Female patient, 34 years old, ASA physical status I, with no prior history of bleeding disorders or anticlotting treatment, underwent epidural anesthesia at the $L_{2}-L_{3}$ level for the surgical treatment of lower limb varicose veins. Eight hours after the regional anesthesia, the patient still presented complete motor blockade (Bromage scale), reduction of thermal and pain sensitivity below $L_{3}$, hyperalgesia in the left plantar region, preserved tendon reflexes, and absence of lumbar pain. A CT scan showed an epidural hematoma in $L_{2}$, with compression of the dural sac. Ten hours after the epidural puncture, there was no regression of neurological signs and symptoms. It was decided, then, to treat the patient with a continuous infusion of methylprednisolone $\left(5.3 \mathrm{mg} . \mathrm{kg}^{-1}\right.$ in the first hour and 1.4 $\mathrm{mg} \cdot \mathrm{kg}^{1} \cdot \mathrm{h}^{-1}$ in the following 23 hours). Eight hours after the beginning of the treatment, the patient recovered thermal and pain sensitivity and presented total regression of the motor blockade. On the $12^{\text {th }}$ hour, she was walking and complained of pain in the surgical wound. The epidural hematoma was not visualized in a CT scan done 14 hours after the beginning of the treatment. The patient was discharged 86 hours after the beginning of the treatment without neurological deficits. A CT scan done after 7 months showed a completely normal spinal canal.

CONCLUSIONS: The efficacy of the conservative approach demonstrated that it is an important alternative to surgery in specific cases. The evaluation of the progression or stabilization of the neurological deficit, especially 8 hours after the epidural puncture, is essential in choosing the treatment.

Key Words: COMPLICATIONS: spinal cord compression, epidural hematoma; ANESTHETIC TECHNIQUES, Regional: epidural. 


\section{INTRODUÇÃO}

A anestesia peridural constitui técnica de anestesia regional de boa indicação para vários procedimentos cirúrgicos, inclusive para aqueles realizados nos membros inferiores. Com esse tipo de bloqueio é possível não apenas prover analgesia, mas também bloqueio motor de graus variáveis e proteção contra o estresse anestésico cirúrgico. Como todo procedimento executado sobre o neuroeixo, a anestesia peridural também pode dar origem a complicações neurológicas. Apesar de descrita na literatura com pequena incidência $(1: 150.000){ }^{1}$, a ocorrência de hematoma no espaço peridural com compressão espinhal após anestesia peridural é uma complicação neurológica grave e que exige a adoção de procedimento terapêutico em curto prazo. O procedimento terapêutico tradicionalmente utilizado tem sido a descompressão cirúrgica de urgência. Mais recentemente, tem sido proposto como alternativa o tratamento com corticosteróides, em determinados casos, com boa recuperação neurológica. O objetivo deste relato foi alertar quanto à possibilidade desse tratamento conservador, em determinadas circunstâncias, tendo em vista a escassez de relatos na literatura internacional com relação a tratamento não-cirúrgico para a ocorrência de hematoma peridural.

\section{RELATO DO CASO}

Paciente do sexo feminino, 34 anos, estado físico ASA I, sem histórico de coagulopatia ou tratamento anticoagulante, submetida à anestesia peridural para tratamento cirúrgico de varizes nos membros inferiores sob regime ambulatorial. Foi realizada punção peridural única, no espaço $L_{2}-L_{3}$, com agulha Tuohy 16G, sem intercorrências. Foram administrados bupivacaína a 0,5\% (125 mg) e fentanil sem conservantes $(100 \mu \mathrm{g})$.

No período pós-operatório, o exame neurológico realizado oito horas após a punção lombar mostrava supressão das sensibilidades térmica e dolorosa abaixo do nível $L_{3}$, hiperalgesia na região plantar esquerda e bloqueio motor completo (segundo a escala de Bromage). Os reflexos tendinosos estavam preservados, não apresentava dor lombar e os sinais vitais eram normais.

Solicitou-se tomografia computadorizada (Figura 1), cujo achado foi o de coleção com densidade de sangue no canal vertebral em $L_{2}$ com compressão do saco dural.

Dez horas após a punção peridural não havia progressão dos sinais e sintomas neurológicos. Iniciou-se tratamento com metilprednisolona em infusão venosa contínua na dose de 5,3 mg. $\mathrm{kg}^{-1}$ na primeira hora e $1,4 \mathrm{mg} \cdot \mathrm{kg}^{-1} \cdot \mathrm{h}^{-1}$ nas 23 horas subseqüentes.

Oito horas após o início do tratamento, a paciente apresentou recuperação das sensibilidades térmica e dolorosa e regressão total do bloqueio motor. $\mathrm{Na} 12^{\mathrm{a}}$ hora, deambulava e referia dor na ferida operatória.
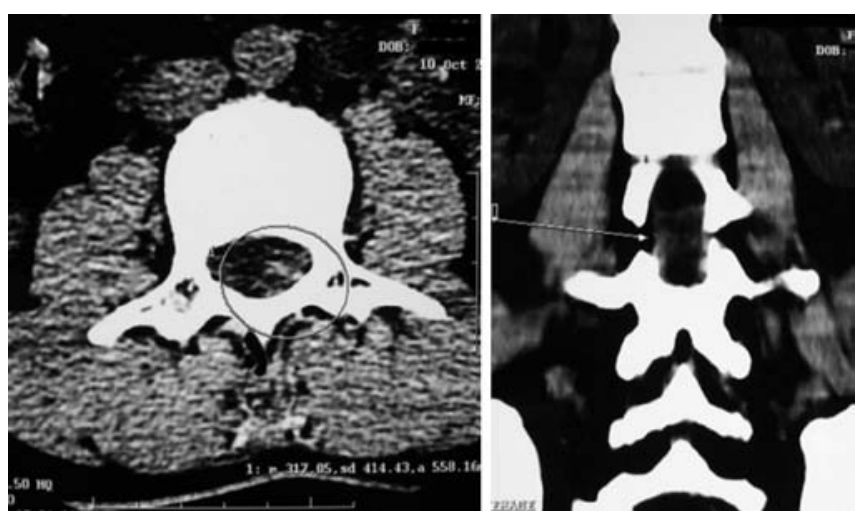

Figura 1 - Tomografia Computadorizada de Coluna Vertebral Oito Horas após a Punção

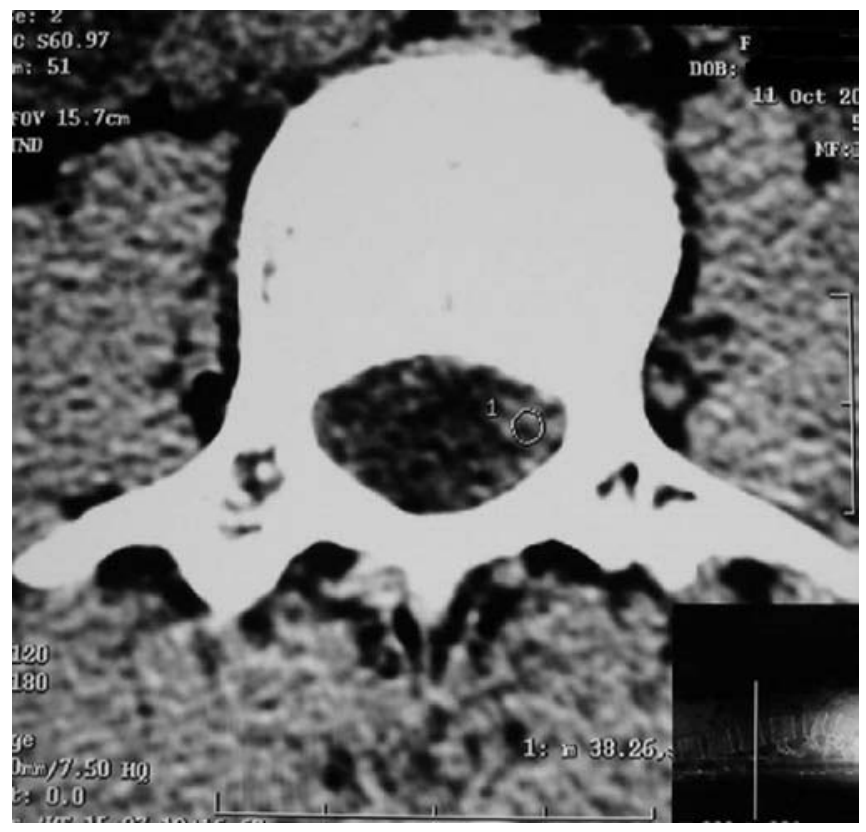

Figura 2 - Tomografia Computadorizada de Coluna Vertebral 14 Horas após o Início do Tratamento

O hematoma peridural não foi visualizado em nova tomografia computadorizada na $14^{\mathrm{a}}$ hora após o início do tratamento (Figura 2).

A paciente recebeu alta hospitalar 86 horas após o início do tratamento conservador, sem comprometimento neurológico. A tomografia computadorizada realizada sete meses depois mostrou o canal vertebral completamente normal.

\section{DISCUSSÃO}

O hematoma peridural em anestesia neuroaxial pode envolver como causa a presença de coagulopatias, o uso de fármacos ou punções traumáticas ${ }^{2,3}$. Alguns casos, no entanto, ocorrem sem qualquer fator de risco aparente ${ }^{3}$. A compressão externa do espaço peridural, tanto pelo coágulo 
quanto pela reação inflamatória desencadeada, pode comprometer o fluxo arterial ou venoso da medula e raízes nervosas espinhais. Isso leva à isquemia e à lesão. Não obstante, o efeito compressivo do hematoma peridural somente se manifesta quando mecanismos compensatórios são esgotados e há aumento da pressão no canal vertebral ${ }^{4}$. O caso relatado mostrou uma paciente em que esses mecanismos provavelmente estavam esgotados. A importância do comprometimento neurológico para o prognóstico, a escoIha do tratamento e a evolução tem sido causa de atenção especial desde a Segunda Guerra Mundial. Desde 1970, foram criadas classificações quanto à gravidade da lesão medular visando à definição do grau de comprometimento neurológico para uma orientação mais adequada da conduta terapêutica. Tais classificações evitam que se adote o critério empírico do diagnóstico de lesão "completa" ou "incompleta". Atualmente, são empregadas duas classificações consideradas muito úteis no estabelecimento da gravidade das lesões medulares. A mais antiga delas, a classificação de Frankel (década de 1970), e a da American Spinal Injury Association - ASIA (década de 1990).

O caso apresentado foi de um quadro clínico neurológico compatível com o nível $\mathrm{B}$ da classificação de Frankel e muito próximo do nível $B$ da ASIA, uma vez que estava presente apenas a função sensitiva abaixo do nível da lesão (Quadros I e II) ${ }^{5}$. Nesses casos, a adoção de conduta terapêutica é

Quadro I - Classificação de Frankel

\begin{tabular}{|ll|}
\hline Grau & Descrição \\
\hline A & Déficit sensitivo e motor completo \\
B & Paraplegia e sensibilidade residual \\
C & Função sensitiva e motora residual não-funcional \\
D & Função sensitiva e motora residual funcional \\
E & Ausência de déficit \\
\hline
\end{tabular}

Quadro II - Classificação da ASIA

\begin{tabular}{|ll|}
\hline Grau & Descrição \\
\hline A & $\begin{array}{l}\text { Completo: ausência de função sensitiva e motora, } \\
\text { inclusive nos segmentos sacrais } S_{4}-S_{5}\end{array}$ \\
C & $\begin{array}{l}\text { Incompleto: função sensitiva preservada e ausência de } \\
\text { função motora abaixo do nível neurológico, inclusive } \\
\text { nos segmentos sacrais } S_{4}-S_{5}\end{array}$ \\
& $\begin{array}{l}\text { Incompleto: função motora preservada abaixo do nível da } \\
\text { lesão e mais da metade dos músculos abaixo do nível } \\
\text { neurológico tem grau de função motora inferior a } 3\end{array}$ \\
& $\begin{array}{l}\text { Incompleto: função motora preservada abaixo do nível } \\
\text { da lesão e pelo menos metade dos músculos abaixo do } \\
\text { nível neurológico tem grau de função motora igual ou } \\
\text { superior a 3 }\end{array}$ \\
& Normal: função motora e sensitiva normais
\end{tabular}

necessária. Tradicionalmente, a descompressão cirúrgica era sempre a indicada e o prognóstico era considerado meIhor quanto mais cedo fosse instituída a intervenção (dentro das primeiras 12 a 36 horas) ${ }^{1,6,7}$. Mais recentemente, tem sido preconizado o tratamento conservador com corticosteróides monitorizado por exames de imagem ${ }^{2,6.8}$.

Considera-se como melhor exame para acompanhamento a ressonância nuclear magnética, aceitando-se como alternativas válidas outros meios diagnósticos, como a mielografia ou a tomografia computadorizada ${ }^{9}$.

A indicação do tratamento conservador deve ser fundamentada no acompanhamento neurológico que possa confirmar a ausência de progressão ou a estabilização dos sintomas neurológicos, sobretudo após a oitava hora pós-punção. Deve-se ressaltar a importância do acompanhamento conjunto por equipes de Anestesiologia e Neurologia. Deve-se considerar ainda que a opção cirúrgica para tratamento pode ser exercida dentro das primeiras 12 a 36 horas após a punção. Assim, se o acompanhamento do quadro neurológico não mostrar regressão satisfatória nas primeiras horas de tratamento conservador, é possível ainda utilizar-se a opção cirúrgica. Os resultados do presente caso demonstraram a eficiência do tratamento conservador como uma alternativa importante ao tratamento cirúrgico, que não é isento de riscos e nem apresenta resultados $100 \%$ satisfatórios ${ }^{6}$. O acompanhamento por exames de imagem tem importância capital na opção pela continuidade, ou não, do tratamento conservador. É permitido concluir que o tratamento cirúrgico invasivo não deve ser a única opção terapêutica quando o diagnóstico de hematoma peridural é feito lastreado em observações clínica e neurológica adequadas e com o suporte radiológico conveniente.

\section{Hematoma after Epidural Anesthesia: Conservative Treatment. Case Report}

Edno Magalhães, TSA, M.D.; Cátia Sousa Govêia, TSA, M.D.; Luís Cláudio de Araújo Ladeira, TSA, M.D.; Laura Elisa Sócio de Queiroz, M.D.

\section{INTRODUCTION}

Epidural anesthesia is a good technique of regional anesthesia for several types of surgeries, including those in the inferior limbs. With this type of block it is possible to promote analgesia, variable degrees of motor blockade, and protection against surgical stress.

Similar to any other procedure in the neuroaxis, epidural anesthesia is also associated with neurological complications. Although described in the literature with a reduced incidence $(1: 150,000){ }^{1}$, epidural hematoma with spinal compression after epidural anesthesia is a severe neurological 
complication, requiring short-term treatment. Traditionally, it has been treated with urgent surgical decompression. More recently, the treatment with corticosteroids in selected cases has been proposed as an alternative, with good neurological recovery. The objective of this report was to call attention to this type of conservative treatment in selected cases, in face of the reduced number of reports in the literature regarding the non-surgical treatment of epidural hematomas.

\section{CASE REPORT}

Female patient, 34 years old, ASA physical status I, with no history of bleeding disorders or anticoagulant treatment, underwent epidural anesthesia for the outpatient surgical treatment of varicose veins in the lower limbs. Epidural puncture in the $L_{2}-L_{3}$ space with a 16G Tuohy needle was done without complications; $0.5 \%$ bupivacaine $(125 \mathrm{mg})$ and fentanyl without preservatives $(100 \mu \mathrm{g})$ were administered. Eight hours after the epidural puncture, the neurological exam showed suppression of thermal and pain sensitivity below $\mathrm{L}_{3}$, hyperalgesia in the left plantar region, and complete motor blockade (according to the Bromage scale). Tendon reflexes were preserved, the patient did not complain of lumbar pain, and vital signs were normal.

A CT scan (Figure 1) showed a collection with blood density in the vertebral canal at the level of $L_{2}$, with compression of the dural sac.

Ten hours after the epidural puncture, neurological signs and symptoms did not evolve. Treatment with continuous intravenous infusion of methylprednisolone was initiated, 5.3 mg. $\mathrm{kg}^{-1}$ in the first hour and $1.4 \mathrm{mg} \cdot \mathrm{kg}^{-1} \cdot \mathrm{h}^{-1}$ in the remaining 23 hours.

Eight hours after the beginning of the treatment, the patient recovered thermal and pain sensitivity and showed complete regression of the motor blockade. In the $12^{\text {th }}$ hour, the patient was able to walk and complained of pain in the surgical wound.

A CT scan done 14 hours after the beginning of the treatment did not show the epidural hematoma (Figure 2).
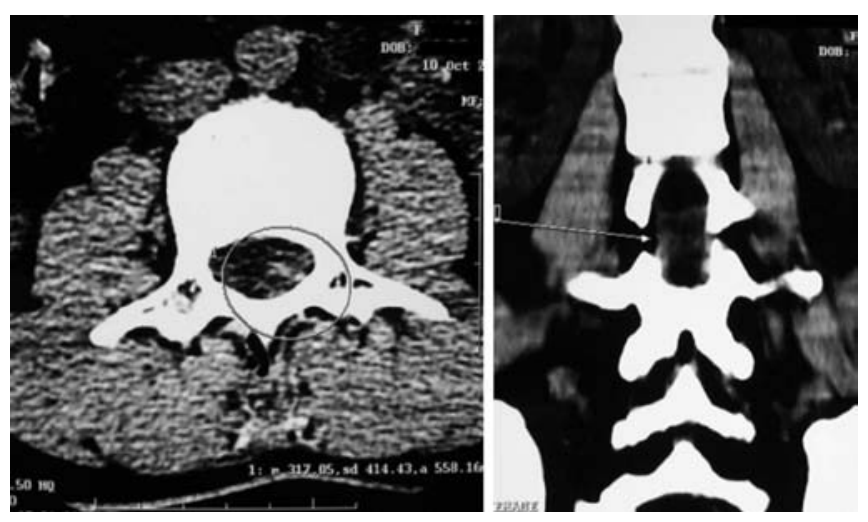

Figure $1-$ CT Scan of the Spine Eight Hours after the Puncture

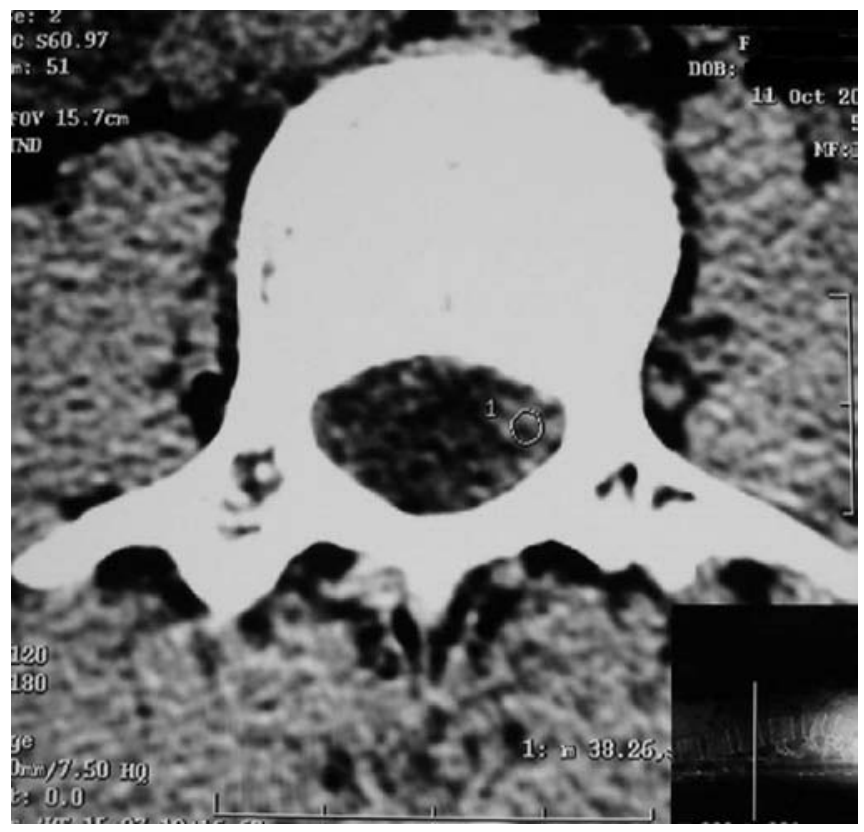

Figure 2-CT Scan of the Spine 14 Hours after the Beginning of the Treatment

The patient was discharged from the hospital 86 hours after the beginning of the treatment without neurological deficits. The CT scan done after seven months showed a completely normal spinal canal.

\section{DISCUSSION}

Epidural hematoma secondary to anesthesia of the neuroaxis can be due to bleeding disorders, use of drugs, or traumatic punctures ${ }^{2,3}$. Some cases, however, occur without any apparent risk factors ${ }^{3}$. External compression of the epidural space, by the blood clot and the subsequent inflammatory reaction, can compromise arterial and venous blood flow to the spinal cord and spinal nerve roots. This causes ischemia and damage. Nonetheless, the compressive effect of the epidural hematoma can manifest only when compensatory mechanisms have been exhausted, with increased pressure in the vertebral canal ${ }^{4}$. The case reported here showed a patient in which those mechanisms were probably exhausted. The importance of the neurological deficit for the prognosis, choice of treatment, and evolution, has been closely studied since World War II. Since 1970, several classifications of the severity of the spinal cord lesion, to define the degree of neurological involvement to better orient the treatment, have been created. Such classifications avoid the adoption of the empirical criterion for the diagnosis of "complete" or "incomplete" lesion. Currently, two classifications considered very useful to establish the presence of spinal cord lesions are being used; the oldest, the Frankel classification (decade of 1970), and the American Spinal Injury Association - ASIA (decade of 1990). 
The case presented here had a neurological clinical picture consistent with the $B$ level of the Frankel classification and very close to the B level of the ASIA classification, since only sensitive function below the lesion was present (Charts I and II) ${ }^{5}$. Those cases require treatment. Traditionally, surgical decompression was always indicated and, the sooner the treatment (within the first 12 to 36 hours), the better the prognosis ${ }^{1,6,7}$. More recently, conservative treatment, monitored by imaging exams, with corticosteroids have been defended ${ }^{2,6,8}$. $\mathrm{MRI}$ is considered the best follow-up exam in those cases, but myelography or CT scan are valid alternatives ${ }^{9}$.

The indication of conservative treatment must be based on neurological follow-up to confirm the absence of evolution or stabilization of the neurological symptoms, especially 8 hours after the puncture. The anesthesiology and neurology teams should follow-up the patient together. One should also consider that the surgical treatment could be instituted in the first 12 to 36 hours after the puncture. Thus, if the evolution of the neurological sings and symptoms do not show satisfactory regression in the first few hours of the conservative treatment, it is still possible to institute the surgical treatment. The results of this case demonstrate the efficiency of the conservative treatment as an alternative to the surgical treatment, which is not devoid of risks and is not $100 \%$ successful ${ }^{6}$.

Chart I - Frankel Classification

\begin{tabular}{|ll|}
\hline Degree & Description \\
\hline A & Complete sensitive and motor deficits \\
B & Residual paraplegia and sensitivity \\
C & Residual non-functional sensitive and motor functions \\
D & Residual functional sensitive and motor functions \\
E & No deficits \\
\hline
\end{tabular}

\section{Chart II - ASIA Classification}

\begin{tabular}{|ll|}
\hline Degree & Description \\
\hline B & $\begin{array}{l}\text { Complete: absence of sensitive and motor functions, } \\
\text { including sacral segments } \mathrm{S}_{4}-\mathrm{S}_{5}\end{array}$ \\
& $\begin{array}{l}\text { Incomplete: preserved sensitive function and absence } \\
\text { of motor function below the neurological level, including } \\
\text { sacral segments } \mathrm{S}_{4}-\mathrm{S}_{5}\end{array}$ \\
& $\begin{array}{l}\text { Incomplete: preserved motor function below the level } \\
\text { of the lesion and more than half of the muscles below } \\
\text { the neurological level have motor function below } \\
\text { grade } 3\end{array}$ \\
& $\begin{array}{l}\text { Incomplete: preserved motor function below the level of } \\
\text { the lesion and at least half of the muscles below the } \\
\text { neurological level have motor function equal or greater } \\
\text { than } 3\end{array}$ \\
& Normal: normal motor and sensitive functions \\
&
\end{tabular}

Follow-up with imaging exams is extremely important on deciding whether or not to continue with the conservative treatment. We can conclude that, based on adequate clinical and neurological observation and with the appropriate radiological support, the surgical treatment is not the only treatment option when the diagnosis of epidural hematoma is made.

\section{REFERÊNCIAS - REFERENCES}

01. Zink M, Rath $M$, Waltensdorfer $A$ et al. - Unilateral presentation of a large epidural hematoma. Anesthesiology, 2003;98:10321033.

02. Inoue K, Yokoyama M, Nakatsuka $\mathrm{H}$ et al. - Spontaneous resolution of epidural hematoma after continuous epidural analgesia in a patient without bleeding tendency. Anesthesiology, 2002;97:735-737.

03. Gilbert A, Owens BD, Mulroy MF - Epidural hematoma after outpatient epidural anesthesia. Anesth Analg, 2002;94:77-78.

04. Castillo D, Tsen LC - Epidural blood patch placed in the presence of an unknown cervical epidural hematoma. Anesth Analg, 2003;97:885-887.

05. Young $W-$ Spinal cord injury levels \& classification. Disponível em: www.sci-info-pages.com/leves.html. Acesso em: 17 mar. 2006.

06. Torres A, Acebes JJ, Cabiol J et al. — Spinal epidural hematomas proagnostic in a series of 22 cases and a proposal management. Neurocirugia (Asturias, Spain), 2004;15:353-359.

07. Groen RJ - Non-operative treatment of spontaneous spinal epidural hematomas: a review of the literature and a comparison with operative cases. Acta Neurochir (Wien), 2004; 146:103-110.

08. Wagner S, Forsting M, Hacke W - Spontaneous resolution of a large spinal epidural hematoma: case report. Neurosurgery, 1996;38:816-818.

09. Wulf $\mathrm{H}-$ Epidural anaesthesia and spinal haematoma. Can $\mathrm{J}$ Anaesth, 1996;43:1260-1271.

\section{RESUMEN}

Magalhães E, Govêia CS, Ladeira LCA, Queiroz LES - Hematoma posterior a la Anestesia Peridural: Tratamiento Conservador. Relato de Caso.

JUSTIFICATIVA Y OBJETIVOS: O hematoma asociado a la compresión espinal después de la anestesia peridural es una complicación neurológica grave, a pesar de la pequeña incidencia relatada (1:150.000). Es un episodio agudo y el tratamiento tradicionalmente aplicado es la descompresión quirúrgica de urgencia. Recientemente, en casos específicos, el tratamiento con corticosteroide ha sido aplicado como alternativa y con una buena recuperación neurológica. El objetivo de este relato fue exponer un caso de hematoma peridural con tratamiento conservador $y$ recuperación neurológica completa.

RELATO DEL CASO: Paciente del sexo femenino, 34 años, estado físico ASA I, sin ningún historial de coagulopatía o terapia anticoagulante, sometida a la anestesia peridural con punción única, en $L_{2}$ $L_{3}$, para tratamiento quirúrgico de várices en los miembros inferiores. Ocho horas después de la anestesia regional, todavía presentaba bloqueo motor completo (escala de Bromage), reducción 
de las sensibilidades térmica y dolorosa por debajo del nivel $L_{3}$, hiperalgesia en la región plantar izquierda, preservación de los reflejos tendinosos y ausencia de dolor lumbar. La tomografía computadorizada reveló hematoma peridural en $L_{2}$ con compresión del saco dural. Diez horas después de la punción peridural no había progresión de las señales y síntomas neurológicos. Se optó entonces por el tratamiento con metilprednisolona en infusión venosa continua $\left(5,3 \mathrm{mg} \cdot \mathrm{kg}^{-1}\right.$ en la primera hora y $1,4 \mathrm{mg} \cdot \mathrm{kg}^{-1} \cdot \mathrm{h}^{-1}$ en las 23 horas siguientes). Ocho horas después del inicio del tratamiento, la paciente recuperó las sensibilidades térmica y dolorosa y la regresión total del bloqueo motor. En la $12^{a}$ hora, deambulaba y refería dolor en la herida operada. El hematoma peridural no se visualizó en una nueva tomografía computadorizada en la $14^{a}$ hora después del inicio del tratamiento. La paciente recibió alta hospitalaria 86 horas después del inicio del tratamiento conservador, sin comprometimiento neurológico. Una tomografía computadorizada de control después de 7 meses, mostró el canal vertebral completamente normal.

CONCLUSIONES: La eficiencia del abordaje conservadora fue una alternativa importante para la intervención quirúrgica en casos específicos. La evaluación de la progresión o estabilización del comprometimiento neurológico, particularmente después de la $8^{a}$ hora posterior a la punción peridural, es esencial para la elección del tratamiento. 